\title{
(RETRACTED) The Reconstruction of Women's Position and Role through Irigaray's Ethics of Sexual Differences in the Culture of Manggarai, Flores, East Nusa Tenggara
}

\author{
Priskardus Hermanto \\ Candra, ${ }^{1}$ Asih Zunaidah, ${ }^{2}$ \\ Frederik Masri Gasa ${ }^{3}$ \\ 1,2,3niversitas Bina Nusantara, Malang- \\ Indonesia
}

Corresponding Author: Priskardus Hermanto Candra, email: priskardushermantocandra@gmail.com, Jl. Araya Mansion No. 8-22 Araya-Malang Jawa Timur 65154

This paper is retracted by the editors due to publication ethics misconducted by authors (simultaneous publication in another journal).

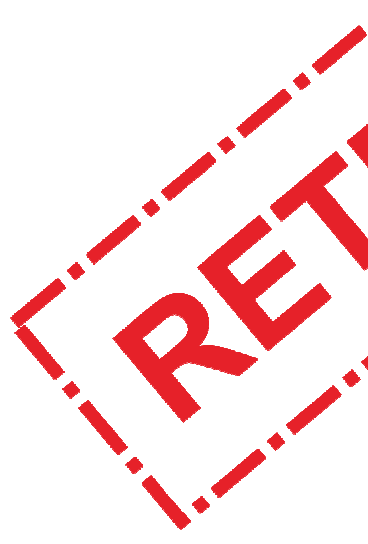

Abstract: This article discusses the reconstruction of women's position and role in the culture of Manggarai, Flores; women's role is defined as 'ata pe'ang' (the outsiders) and followed by a series of obligations imposed on them. In this pattern, women have a fragile cultural practice position and accept it to show obedience to customs and culture. Using Luce Irigaray's ethics of sexual differences, this paper intends to redefine culturallymarginalized women's roles and positions: Irigaray's notion is a means to map the differences bet cen women men. The differences are not used to compare men's superiority over women; instead, it is consider a virtue inherent in men and women. Irigaray's theory of thics of sexpoldifferen s is relevant to the cultural conte of Man ai- es, especially in identifying and breaking the chair of vo "ance ainstwor, en that is visible, hidde' (symboli $r^{\prime}$ an or ang from caltural determination This qua at. eseanch uses a wase study approach the data are ary data stained using literature studies from và us sources. Rese rchers found that the persistence $r$ women's rginalizatic $A$ is due to customary concepts that are ' $\&$ en.' Reconstuction of cultural and custom valua br gharay, ethics of sexual differences needs $t b_{c}$ one so that yomen are valued as dignified i. idu

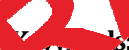

ethi ,gender; violence against women; culture; yranggarai-Flores

Abstral Ârtikel ini membahas rekonstruksi posisi dan peran peren.muan dalam budaya Manggarai, Flores. Peran perempuan di Nefinisikan sebagai 'ata pe'ang' (orang luar) dan diikuti oleh serangkaian kewajiban yang dibebankan kepada mereka. Dalam pola ini, perempuan memiliki posisi praktik budaya yang rapuh dan menerima dengan menunjukkan ketaatan pada adat istiadat dan budaya. Menggunakan etika Luce Irigaray tentang perbedaan seksual, makalah ini bermaksud untuk mendefinisikan kembali peran dan posisi perempuan yang terpinggirkan secara budaya; Pengertian Irigaray adalah sarana untuk memetakan perbedaan antara perempuan laki-laki. Perbedaan tersebut tidak digunakan untuk membandingkan superioritas laki-laki atas perempuan; sebaliknya, itu dianggap sebagai kebajikan yang melekat pada pria dan wanita. Teori Irigaray tentang etika perbedaan seksual relevan dengan konteks budaya Manggarai-Flores, terutama dalam mengidentifikasi dan 